\title{
Relationship between metal levels in the vent mussel Bathymodiolus azoricus and local microhabitat chemical characteristics of Eiffel Tower (Lucky Strike)
}

\author{
Inês Martins ${ }^{a,}{ }^{*}$, Richard P. Cosson ${ }^{b}$, Virginie Riou ${ }^{a, c}$, Pierre-Marie Sarradin $^{d}$, Jozée Sarrazin $^{d}$, Ricardo
} S. Santos ${ }^{\mathrm{a}}$ and Ana Colaço ${ }^{\mathrm{a}}$

a IMAR, DOP- Department of Oceanography and Fisheries, University of the Azores, 9901-862 Horta, Portugal

${ }^{b}$ Laboratoire de Biologie Marine, ISOMer, MMS, Université de Nantes, BP 92208, 44322 Nantes, France

${ }^{\mathrm{C}}$ Department of Analytical and Environmental Chemistry, Vrije Universiteit Brussel, B-1050 Brussels, Belgium

${ }^{\mathrm{d}}$ Département Études des Ecosystèmes Profond, Laboratoire Environnement Profond Ifremer centre de Brest, BP70, F-29280 Plouzané, France

* Corresponding author : I. Martins, Tel.: +351 292207800; fax: +351 292200411, email address : imartins@uac.pt

\begin{abstract}
:
The turbulent mixing of hydrothermal hot fluid with cold seawater creates large chemical gradients at a small spatial scale that may induce variable physiological and biochemical adaptations within the vent fauna. The adaptation to such a variable environment by the vent mussel Bathymodiolus azoricus relies on a dual symbiosis hosted in the gills, and digestion of particulate organic matter. The surrounding environment not only provides the necessary energy sources and suspended organic particles for the vent mussel nutrition, but also potentially toxic compounds such as metals. Our main goal was to see if there is a relation between metal accumulation in mussel organs and the chemical characteristics of their close environment. Mussels were collected at six locations in a cold part of the Eiffel Tower fluid-seawater mixing zone, characterized by distinct chemical compositions. Metals (Cd, $\mathrm{Cu}, \mathrm{Fe}$ and $\mathrm{Zn}$ ) and metallothioneins were quantified in the gills and digestive gland. The physiological condition of the sampled mussels was also evaluated using tissues and gill indices. Our study indicates that the accumulation of metals in B. azoricus is related to their spatial distribution and linked to fine scale environmental conditions that influence the physiological status of the organism.
\end{abstract}

\section{Research highlights}

Bathymodiolus azoricus were collected along a hydrothermal chemical gradient. Metals and metallothioneins were quantified in the gills and digestive gland. Metal levels reflect mussels spatial distribution and physiological status. Metallothionein levels are high and almost constant.

Keywords: Metals; Metallothioneins; Bathymodiolus azoricus; Hydrothermal vent; Environmental conditions; Physiological condition; Spatial distribution

\section{Introduction}

Deep-sea hydrothermal vents are unpredictable habitats characterized by heterogeneous venting. Turbulent mixing of hot fluids with cold seawater creates large 
39 gradients in the environmental conditions (Tunnicliffe 1991; Childress et al. 1992; Le

40 Bris et al. 2001) that may induce small scale variability in physiological and

41 morphological features from one individual to the other (Tunnicliffe 1991). Therefore, it

42 is generally assumed that abiotic factors, such as fluid flow, temperature and chemical

43 composition, play a major role in structuring vent communities (Sarradin et al. 1999;

44 Sarrazin et al. 1999; Cuvelier et al. 2009). Investigating the interactions between vent

45 fauna and their environment is an essential step to understand the adaptation of species to

46 such stochastic ecosystems.

47 The vent mussel Bathymodiolus azoricus is the dominant megafaunal species at 48 Lucky Strike hydrothermal field (Desbruyères et al. 2001) and the main constituent of

49 Eiffel Tower edifice assemblages (Cuvelier et al. 2009). The main source of energy of $B$.

50 azoricus is provided by thiotrophic and methanotrophic bacteria living in symbiosis in

51 their gills (Fiala-Médioni et al. 2002; Duperron et al. 2006; Riou et al. 2008). In this

52 association both partners have nutritional benefits. While the endosymbionts fix inorganic

53 carbon (e.g. $\mathrm{CO}_{2}$ and $\mathrm{CH}_{4}$ ) into organic matter using chemical energy from the oxidation

54 of reduced sulfur and methane compounds, the host mussel facilitates their access to the

55 essential substrates (e.g. $\mathrm{O}_{2}, \mathrm{CO}_{2}$ and reduced compounds) (Stewart et al. 2005).

56 Nevertheless, the existence of a functional gut (Le Pennec et al. 1990) suggests that $B$.

57 azoricus may use suspension-feeding as a secondary pathway of nutrition (Martins et al.

58 2008; Colaço et al. 2009; De Busserolles et al. 2009; Riou et al. 2010). The ability of the

59 mussel to filter not only provides the necessary particulate material and substrates to

60 fulfill the heterotrophic and chemoautotrophic processes (Le Pennec et al. 1990) but may

61 also increase metal uptake by exposing the tissues to metal-rich vent fluids (Charlou et al. 
62 2000; Douville et al. 2002; Kádár et al. 2005b). Therefore, the distribution of the vent

63 mussels along the chemical gradient can also be linked to their ability to sustain highly

64 variable metallic bioavailable forms.

65 The behavior and speciation of metallic complexes have an important biological

66 significance because they may strongly affect the uptake process of the organism

67 (Simkiss 1998). Consequently, metal bioaccumulation in vent mussels reflects partly the

68 abundance and chemical specificity of the metal in the environment surrounding the

69 mussels and also individual physiological functioning (Cosson et al. 2008).

70 Metallothioneins (MTs) are low molecular weight metalloproteins with a high cysteine

71 content, a non-enzymatic nature and a strong affinity for metal cations $(\mathrm{Cd}, \mathrm{Cu}, \mathrm{Zn})$

72 enabling MTs to be distinguished from most other proteins (Amiard et al. 2006). MT

73 induction in bivalve mollusks is often presumed to occur as a result of exposure to metals

74 in contaminated environments. The role of MTs in metal intracellular regulation and

75 detoxification is well established (Langston et al. 1989; Viarengo et al. 1993; Geret et al.

76 1998; Cosson 2000; Hamza-Chaffai et al. 2000; Hardivillier et al. 2006; Company et al.

77 2010). Metallothioneins protect cells against damages induced by oxidative stress (Sato et

78 al. 1993; Viarengo et al. 2000) and may be considered both as biomarkers of metal

79 exposure and physiological stress in general (Cosson 2000; Kondoh et al. 2003).

80 Metal regulation and storage in B. azoricus tissues have been studied by several authors

81 (Cosson et al. 1995; Martins et al. 2001; Company et al. 2004; Kádár et al. 2005b; Colaço

82 et al. 2006; Cosson et al. 2008; Martins et al. 2009). However, the link between fine scale

83 environmental variations and metal accumulation is still unknown. Here, we describe

84 levels of essential $(\mathrm{Cu}, \mathrm{Fe}$ and $\mathrm{Zn})$ and non essential $(\mathrm{Cd})$ metals in gills and digestive 
85 gland of B. azoricus individuals, collected along the cold part of the Eiffel Tower fluid-

86 seawater mixing zone. Our main goal was to investigate the relation between the amount

87 of metals accumulated in mussel organs and the chemical variations of their immediate

88 environment that may influence their physiological condition. The study provides novel

89 and important information regarding the adaptation of B. azoricus to extreme vent

90 environments, in particular the ability of this species to manage the small scale

91 environment fluctuations and the consequent supply of metals in dissolved and particulate

92 forms.

93

\section{2. Material and Methods}

95 2.1. Study area

96 The Lucky Strike (LS) hydrothermal vent field ( $\left.37^{\circ} 18^{\prime} \mathrm{N}, 32^{\circ} 16^{\prime} \mathrm{W}\right)$ extends

97 over $1 \mathrm{~km}^{2}$ on the summit of a prominent volcano, at the center of the LS segment of the

98 Mid-Atlantic Ridge (MAR) (Ondréas et al. 2009). The LS field consists on three

99 seamounts distributed around a large lava lake (Fig. 1) at depths varying from 1650 to

$1001750 \mathrm{~m}$ (Fouquet et al. 1995; Ondréas et al. 2009). Site to site variations in hydrothermal

101 fluid temperatures $\left(170\right.$ to $324^{\circ} \mathrm{C}$ ), as well as gas and metal concentrations, suggest the

102 presence of two fluid sources (Charlou et al. 2000). Eiffel Tower is a well-defined

103 hydrothermal edifice and one of the most active at LS. Located in the south-eastern

104 region of the vent field, Eiffel Tower extends $11 \mathrm{~m}$ in height and $20 \mathrm{~m}$ in width. The

105 work developed by Cuvelier et al. (2009) divided the edifice structure into two parts, a

106 'tower' structure with the summit at $1681 \mathrm{~m}$ depth and a 'periphery' that is located on the

107 seafloor at depths varying from 1688 to $1692 \mathrm{~m}$. Bathymodiolus azoricus is the dominant 
108 megafaunal species that covers the edifice walls of Eiffel Tower, being mainly distributed

109 on the west edges of the edifice (Desbruyères et al. 2001; Cuvelier et al. 2009).

111 2.2. Sampling

112 The MoMARETO cruise (Sarrazin et al. 2006) was held in August 2006 on the

113 French R/V "Pourquoi Pas?" with the Remotely Operated Vehicle (ROV) "Victor 6000".

114 During this cruise studies were focused on the spatial and temporal dynamics of

115 hydrothermal communities colonizing the MoMAR zone, centering most of the dives on

116 LS hydrothermal field. Fauna and chemical data were collected on the $11 \mathrm{~m}$ high Eiffel

117 Tower on a total of twelve locations (C1-C12) that were considered to be representative

118 of B. azoricus distribution around the sulfide edifice. The results are reported in more

119 detail in various publications (Cuvelier et al. 2009; De Busserolles et al. 2009; Sarradin et

120 al. 2009). For the present study, six locations (C1, C3, C4, C5, C10 and C12) were

121 chosen for sampling (Fig. 1). Mussel assemblages were collected using the ROV "Victor

1226000 " arm grab. On board, the collected mussels were rinsed in sea water and the length,

123 width and height of the shells recorded. The gills and digestive gland were dissected and

124 preserved at $-20{ }^{\circ} \mathrm{C}$ until freeze-drying and analysis of metals and MTs contents. The

125 chemical conditions within the mussel assemblages were measured. Tracers of fluid

126 dilution (temperature and $\mathrm{pH}$ ), energy source (total dissolved sulfide, TdS) and potential

127 bioavailable metal sources (total dissolved copper, $\mathrm{TdCu}$, and total dissolved iron, $\mathrm{TdFe}$ )

128 were analyzed at the scale of the animals at the 6 sampling locations (2-5 water samples

129 per location). Technical limitations did not allow the in situ measurement of methane

$130\left(\mathrm{CH}_{4}\right)$. Water sampling and preservation are described in detail elsewhere (Sarradin et al. 
131 2009). Temperature was measured with an autonomous temperature probe (NKE)

132 attached to the sampling inlets. The $\mathrm{pH}$ measurements were performed on board at $25^{\circ} \mathrm{C}$

133 using a Metrohm ${ }^{\circledR} \mathrm{pH}$-meter with a combined $\mathrm{pH}$ electrode (Ingold ${ }^{\circledR}$ ) for sulfide-rich

134 medium ( \pm 0.01 precision) after calibration with NBS buffers ( $\mathrm{pH} 4$ and 7). $\mathrm{TdCu}$ was

135 measured in the laboratory by Stripping ChronoPotentiometry (SCP) with a gold

136 electrode (Riso et al. 1997). TdS and TdFe were measured using the CHEMINI in situ

137 analyzer (Vuillemin et al. 2009).

138

\section{2.3. Samples preparation}

140 Approximately $100 \mathrm{mg}$ of lyophilized and grounded tissues were homogenized in

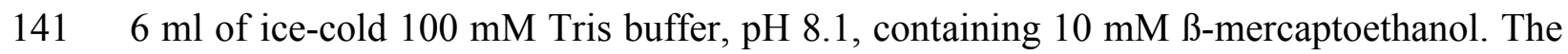
142 homogenates were centrifuged for $30 \mathrm{~min}$ at $25000 \mathrm{~g}$, at $4{ }^{\circ} \mathrm{C}$ and an aliquot $(1 \mathrm{ml})$ of the 143 supernatant was used for metallothionein determination. The remaining supernatants and 144 the pellets were digested simultaneously with nitric acid $\left(65 \%\right.$ v/v, p.a.) at $60{ }^{\circ} \mathrm{C}$ for metal 145 analysis. After digestion, solutions were dried at $60{ }^{\circ} \mathrm{C}$ and the resulting material was 146 solubilized with $2 \mathrm{ml}$ of $0.5 \mathrm{~N} \mathrm{HNO}_{3}$.

148 2.3.1. Metal analyses

149 Copper, $\mathrm{Fe}$ and $\mathrm{Zn}$ were determined by flame atomic absorption 150 spectrophotometry (GBC-Avanta $\Sigma$ ), with deuterium background correction. Cadmium 151 was determined by graphite furnace atomic absorption spectrometry (Perkin-Elmer, 152 Zeeman 4110ZL). The accuracy and precision of the method used were established by 153 regular analysis of certified reference materials, mussel tissue CE278 (European 
154 Reference Materials of Belgium) and lobster hepatopancreas TORT-2 (National Research

155 Council of Canada). Certified reference materials and blanks were taken through the

156 procedure in the same way as the samples. Measured values and certified values are given

157 in Table 1 as $\mu \mathrm{g} \mathrm{g}^{-1}$ of dry weight. The $\mathrm{Zn}$ levels measured in the certified material 158 presented overestimated values. Metal levels in mussel whole tissues were also 159 expressed as $\mu \mathrm{g} \mathrm{g}^{-1}$ of dry weight.

\subsubsection{Metallothionein analysis}

162 The $1 \mathrm{ml}$ aliquot of the supernatant, obtained from the centrifugation described in 163 section 2.3 , was heat-denatured $\left(90^{\circ} \mathrm{C}, 15 \mathrm{~min}\right)$ and centrifuged for $10 \mathrm{~min}$ at $13000 \mathrm{~g}$, 164 at $4^{\circ} \mathrm{C}$, in order to separate the heat stable metallothionein (MT) from thermo labile 165 compounds. The heat stable fractions were used for the quantification of MT by 166 Differential Pulse Polarography (DPP) according to Olafson and Sim (1979) and 167 Thompson and Cosson (1984). A standard addition calibration curve was obtained using 168 rabbit liver MT-I as reference. Results were expressed as $\mu \mathrm{g} \mathrm{g}^{-1}$ of dry weight.

\section{2.4. Condition indices}

171 The tissue condition index (TCI) and gill index (GI) were used to assess the 172 physiological condition of the collected mussels. The tissue condition index was 173 determined according to Voets et al. (2006): TCI = tissues dry weight (g)/mussel shell 174 volume $(\mathrm{ml})$. The mussel shell volume $\left(\mathrm{V}_{\mathrm{m}}\right)$ was calculated based on the length, width 175 and height of the mussel shell with the formula: $\mathrm{V}_{\mathrm{m}}=($ length $\mathrm{x}$ width $\mathrm{x}$ height $) / \mathrm{C}$. C is a 176 constant determined empirically as follows. The volume of the space enclosed by the 
177 shell valves $\left(\mathrm{V}_{\mathrm{m}}\right)$ of 132 B. azoricus individuals between 24 and $93 \mathrm{~mm}$ lengthy was

178 measured to the nearest $\mathrm{ml}$ by displacement of water in a graduated cylinder. Empty

179 shells were sealed with parafilm before immersion in the liquid. Values of $\mathrm{V}_{\mathrm{m}}$ were then

180 plotted against the volume of the cube $\left(\mathrm{V}_{\text {cube }}\right)$ obtained by multiplying the length $\mathrm{x}$ width

$181 \mathrm{x}$ height. The regression line was calculated and the slope (constant C) amounted to $2.6 \pm$

$1820.03\left(\mathrm{R}^{2}=0.988, \mathrm{p}<0.05\right)$ (unpublished data). The gill index was calculated as follows: GI

$183=($ gill tissue dry weight $(\mathrm{g}) /$ shell volume $(\mathrm{ml})) \times 10$.

185 2.5. Data analysis

186 All data were tested for normality by normal probability plots and homogeneity of

187 variances by Bartlett's test. Since data did not respect the former assumptions of 188 parametric analysis, non-parametric tests were applied. Mann-Whitney U test (M-W) and

189 Kruskal-Wallis ANOVA by ranks (K-W) were used to evaluate the variability between

190 the different groups of samples. Dunn's test was used as post hoc comparison of means.

191 Principal Component Analysis (PCA) was used to investigate the spatial patterns of the

192 relative levels of analyzed metals and metallothioneins within the individuals of the 6

193 locations. Data was standardized before PCA analysis. The tests were performed with

194 STATISTICA 6.0 (StatSoft). Differences were considered significant when $\mathrm{p}<0.05$.

195 Statistical methods were selected in accordance with Zar (1999).

196

197 3. Results

198 3.1. Environmental conditions 
200 locations were extracted from De Busserolles et al. (2009) and summarized in Table 2.

201 Mean temperatures and $\mathrm{pH}$ varied from 4.8 to $8.8^{\circ} \mathrm{C}$ and 6.0 to 7.1 respectively. The

202 location with the warmest temperature value (C10) also had the highest concentrations of

203 TdS and TdFe and the lowest concentration of $\mathrm{TdCu}$. An opposite pattern was observed

204 at the coolest location since C1, C5 and C12 had the lowest TdS and TdFe 205 concentrations. However, TdCu concentrations did not follow a similar trend.

\section{3.2. Mussel sizes}

208 Table 3 gives the number of mussels collected at each location and the mean shell

209 allometric parameters. The mussels from locations C3 and C10 have significantly larger

210 shell length than mussels from locations $\mathrm{C} 1, \mathrm{C} 4, \mathrm{C} 5$ and $\mathrm{C} 12(\mathrm{~K}-\mathrm{W}, \mathrm{p}<0.05)$. However,

211 mussels from $\mathrm{C} 3$ and $\mathrm{C} 10$ have significantly similar shell lengths $(\mathrm{K}-\mathrm{W}, \mathrm{p}>0.05)$ as do

212 the mussels from $\mathrm{C} 1, \mathrm{C} 4, \mathrm{C} 5$ and $\mathrm{C} 12(\mathrm{~K}-\mathrm{W}, \mathrm{p}>0.05)$.

\section{3.3. Metal and MT levels}

215 Mean metal and MT levels in the gills and digestive gland of mussels collected at

216 the 6 locations, are given in Figures 2. In brief, whatever the collection locations, $\mathrm{Cd}$ 217 (Fig. 2-a), Fe (Fig. 2-c) and MT (Fig. 2-e) presented higher levels in the digestive gland.

218 Copper was present preferentially in the gills (Fig. 2-b) except for mussels from the 219 coolest location (C12). Regarding Zn, no relationship was observed between gills or 220 digestive gland levels and locations (Fig. 2-d). 


\subsubsection{Metal organotropism between locations}

223 Cadmium levels were statistically higher in the digestive gland than in the gills

224 (M-W, $\mathrm{p}<0.05$ ) for mussels from the locations $\mathrm{C} 3, \mathrm{C} 4$ and $\mathrm{C} 5$. On the other hand, $\mathrm{Cu}$ 225 levels were statistically higher in the gills than in the digestive gland ( $M-W, p<0.05)$, 226 except for $\mathrm{C} 12$, where $\mathrm{Cu}$ levels were higher in the digestive gland $(\mathrm{M}-\mathrm{W}, \mathrm{p}<0.05)$. No

227 significant difference was observed between $\mathrm{Cd}$ levels of both tissues (M-W, $\mathrm{p}>0.05)$ in 228 mussels from the warmest location $(\mathrm{C} 10)$ or from the coolest one $(\mathrm{C} 12)$. At the 6 sampled

229 locations, Fe and MT levels were higher in the digestive gland than in the gills (M-W, $230 \mathrm{p}<0.05)$. At the location $\mathrm{C} 1$ and $\mathrm{C} 10$, gills showed higher levels of $\mathrm{Zn}$ than the digestive 231 gland $(\mathrm{M}-\mathrm{W}, \mathrm{p}<0.05)$, the opposite was found in mussels from location $\mathrm{C} 5$. No 232 statistically significant differences were found for $\mathrm{Zn}$ levels between both tissues (M-W, $233 \mathrm{p}>0.05)$ in mussels from locations $\mathrm{C} 3, \mathrm{C} 4$ and $\mathrm{C} 12$.

\subsubsection{Metal levels between locations}

236 The gills of mussels from locations $\mathrm{C} 1, \mathrm{C} 3, \mathrm{C} 4$ and $\mathrm{C} 10$ showed similar levels of

$237 \mathrm{Cd}(\mathrm{K}-\mathrm{W}, \mathrm{p}>0.05)$, lower than those observed for locations $\mathrm{C} 5$ and $\mathrm{C} 12(\mathrm{~K}-\mathrm{W}, \mathrm{p}<0.05)$, 238 which were not significantly different $(\mathrm{K}-\mathrm{W}, \mathrm{p}>0.05)$. The digestive glands of mussels

239 from the locations $\mathrm{C} 1, \mathrm{C} 4, \mathrm{C} 10$ and $\mathrm{C} 12$ showed similar levels of $\mathrm{Cd}(\mathrm{K}-\mathrm{W}, \mathrm{p}>0.05)$ as 240 did mussels from locations $\mathrm{C} 3$ and $\mathrm{C} 5(\mathrm{~K}-\mathrm{W}, \mathrm{p}>0.05)$. The gills of mussels from the 6 241 different locations showed similar levels of $\mathrm{Cu}(\mathrm{K}-\mathrm{W}, \mathrm{p}>0.05)$ with the exception of 242 those from $\mathrm{C} 4$, which had the lowest values $(\mathrm{K}-\mathrm{W}, \mathrm{p}<0.05)$. The digestive glands of 243 mussels from $\mathrm{C} 1, \mathrm{C} 4$, and $\mathrm{C} 3, \mathrm{C} 5, \mathrm{C} 10$ showed similar levels of $\mathrm{Cu}$, respectively (K-W, $244 \mathrm{p}>0.05)$. The gills of mussels from the different locations showed similar levels of Fe (K- 
$245 \mathrm{~W}, \mathrm{p}>0.05)$ with the exception of those from locations $\mathrm{C}$, which had the lowest values

$246(\mathrm{~K}-\mathrm{W}, \mathrm{p}<0.05)$. The digestive glands of mussels from the different locations showed

247 similar levels of $\mathrm{Fe}(\mathrm{K}-\mathrm{W}, \mathrm{p}>0.05)$ with the exception of those from the locations $\mathrm{C} 4$,

248 which exhibited the highest values $(\mathrm{K}-\mathrm{W}, \mathrm{p}<0.05)$. However, concentrations at $\mathrm{C} 4$ were

249 not significantly different from those at $\mathrm{C} 5(\mathrm{~K}-\mathrm{W}, \mathrm{p}>0.05)$. The gills of mussels from the

250 locations $\mathrm{C} 1, \mathrm{C} 3, \mathrm{C} 4, \mathrm{C} 5$ and locations $\mathrm{C} 10$ and $\mathrm{C} 12$ showed similar levels of $\mathrm{Zn}$ (K-W,

$251 \mathrm{p}>0.05$ ). The lowest mean level was observed at $\mathrm{C} 4$ while the highest values were

252 measured at $\mathrm{C} 10$ and $\mathrm{C} 12$. The digestive glands of mussels from locations $\mathrm{C} 1, \mathrm{C} 3, \mathrm{C} 4$

253 and $\mathrm{C} 10$ showed similar levels of $\mathrm{Zn}(\mathrm{K}-\mathrm{W}, \mathrm{p}>0.05)$. The highest mean level of $\mathrm{Zn}$ was

254 observed at C12. No difference could be established between MT levels in both organs of

255 mussels with the exception of mussels from location C12. Here, the gills had higher

256 levels of MT than the gills of mussels from $\mathrm{C} 4$ and $\mathrm{C} 10(\mathrm{~K}-\mathrm{W}, \mathrm{p}<0.05)$, while the

257 digestive glands had higher levels of MT than the digestive glands of mussels from C1

$258(\mathrm{~K}-\mathrm{W}, \mathrm{p}<0.05)$.

259

260 3.3.3. $P C A$

261 A principal component analysis (PCA) was used to investigate the spatial

262 distribution of mussels relative levels of metals and MT in both organs, and shell length,

263 over the individuals. For each tissue, PCA clearly separated individuals between the

264 locations according to their relative levels of the different metals and MT, and shell

265 length (Fig. 3-4). The first two principal components accounted for $56.4 \%$ of the

266 variability in the metal levels in the gills, with $34.5 \%$ on axis 1 and $21.9 \%$ on axis 2 (Fig.

267 3A). Several groups of mussels were discriminated. Starting from the right side of axis 1 
268 and moving towards the left, mussels from C4 were followed by those from C1, C3 and

269 C12. This axis discriminates according to the relative levels of $\mathrm{Cu}, \mathrm{Zn}, \mathrm{Cd}$, and MT (Fig.

270 3B). On the second axis, mussels from $\mathrm{C} 10$ are discriminated from $\mathrm{C} 5$ mussels with

271 respect to the relative levels of $\mathrm{Fe}$ and shell length.

272 In the digestive gland, the PCA showed that the first two axes accounted for 60.8

$273 \%$ of variability between the mussels, with $38.9 \%$ explained by axis 1 and $21.9 \%$ by axis

2742 (Fig. 4A). Axis 1 discriminates according to the relative levels of $\mathrm{Zn}, \mathrm{Cd}, \mathrm{Cu}$ and $\mathrm{MT}$,

275 while axis 2 discriminates positively Fe levels and negatively the shell length (Fig. 4B).

276 Mussels from locations $\mathrm{C} 1, \mathrm{C} 3, \mathrm{C} 4$ and $\mathrm{C} 10$ (right of axis 1) separated from $\mathrm{C} 12$ mussels

277 (left of axis 1). Mussels from C10 were separated from those from other locations along $278 \quad$ axis 2.

279 Results of these two PCAs show that: (i) there is a clear segregation in the metal 280 accumulation by $B$. azoricus from different sampling locations, (ii) this segregation is 281 observed for both studied organs, (iii) the size of the mussels is also a discriminating 282 factor.

283

284 3.3.4. TCI and GI

285 The mean values of tissue condition index (TCI) and gill index (GI) in mussels 286 collected at the 6 locations are shown in Fig. 5. In order to limit the effect of mussel size, 287 comparisons were made among mussels from locations C1, C4, C5 and C12 (mean length $288<6 \mathrm{~cm}$ ) and among mussels from locations $\mathrm{C} 3$ and $\mathrm{C} 10$ (mean length $>6 \mathrm{~cm}$ ). Therefore, 289 we observed that mussels from location $\mathrm{C} 1$ and $\mathrm{C} 4$ showed the highest mean TCI and GI 
290 (K-W, $\mathrm{p}<0.05)$. The TCI in mussels from location $\mathrm{C} 10$ was higher than in mussels from

291 location $\mathrm{C} 3(\mathrm{M}-\mathrm{W}, \mathrm{p}<0.05)$, although their GI were not different $(\mathrm{M}-\mathrm{W}, \mathrm{p}>0.05)$.

\section{Discussion}

The Eiffel Tower is an active edifice in the LS vent field largely colonized by $B$. azoricus faunal assemblages (Desbruyères et al. 2001; Cuvelier et al. 2009; Sarradin et al. 2009). The mean temperatures varied from 4.8 to $8.8^{\circ} \mathrm{C}$. This is a relative narrow range

297 for vent ecosystems (De Busserolles et al. 2009), although it is characteristic of the cold 298 part of the mixing zone where a low percentage of hot hydrothermal fluids $\left(\mathrm{T}=324^{\circ} \mathrm{C}\right.$, $299 \mathrm{pH}$ 3.5-4.2) mixes with cold seawater ( $\mathrm{T}=4.4^{\circ} \mathrm{C}, \mathrm{pH}$ 7.8) (Sarradin et al. 2009). Such a

300 mixing zone is subject to short temporal (seconds) and spatial (centimeters) gradients of 301 the physicochemical conditions, which may critically affect the concentrations of the 302 substrates used as energy and carbon sources for chemosynthetic processes (Le Bris et al. 303 2003; Stewart et al. 2005). Consequently we can hypothesize that local environmental

304 variations influence the physiological status of the vent mussels. Temperature has a semi-

305 conservative behavior and is affected by physical processes occurring at vents. At known

306 sites it can be used as a tracer of hydrothermal fluids (Sarradin et al. 2008; Sarradin et al.

307 2009). Moreover, De Busserolles et al. (2009) demonstrated that, at Eiffel Tower, 308 temperature is positively correlated with dissolved sulfide and iron concentrations and

309 negatively correlated with dissolved $\mathrm{Cu}$. However, it seems that both dissolved and

310 particulate forms of metals are not controlled by a simple dilution process, as shown by

311 Sarradin et al. (2008) in two distinct microhabitats of the East Pacific Rise (EPR)

312 hydrothermal field. Other factors that may account for metal availability and 
313 accumulation in vent mussels include (i) the ability of metals (like $\mathrm{Cd}, \mathrm{Cu}, \mathrm{Fe}$ and $\mathrm{Zn}$ ) to

314 form metallic complexes with sulfides in plume or conduit surfaces (Feely et al. 1994),

315 which precipitates and are exported in the buoyant plume settling close to the organism

316 (Trefry et al. 1985; Trocine et al. 1988), and (ii) the occurrence of metallic complexes

317 dissolution/oxidation reactions in oxygen-enrich mixing zones (Sarradin et al. 2008;

318 Sarradin et al. 2009). The PCAs performed in this study (Figs. 3-4) indicated that mussels

319 from location $\mathrm{C} 12$ are clearly distinct from mussels from location $\mathrm{C} 4$ in terms of the

320 amounts of metals present in their tissues.

321

322 4.1. Location C12

323 Among the sampled locations, $\mathrm{C} 12$ is characterized by the lowest temperature,

324 highest $\mathrm{pH}$ and one of the lowest concentrations of TdS. It represents an environment

325 where the hydrothermal fluid is largely diluted. In these conditions the energy supply

$326\left(\mathrm{H}_{2} \mathrm{~S}\right.$ and $\left.\mathrm{CH}_{4}\right)$ is limited and metal levels are relatively low. The bioaccumulation

327 pathway of metals is not strictly governed by the concentrations of these metals in the

328 environment but is strongly influenced by the hydrophilic and hydrophobic properties of

329 the dissolved metals (Sarradin et al. 2009). The high concentrations of total dissolved $\mathrm{Cu}$

$330(\mathrm{TdCu})$ measured at $\mathrm{C} 12$, and the high concentrations of $\mathrm{Cu}$ found in the mussel gills

331 from this location, seem to be related. A recent study carried out by Sarradin et al.,

332 (2009) on the same edifice showed that most of the dissolved $\mathrm{Cu}$ results from an

333 oxidative redissolution process. This phenomenon results not only in a secondary source

334 of dissolved $\mathrm{Cu}$ to the vent mussels but also in a $\mathrm{Cu}$ fraction more bioavailable to the

335 organisms, as most of the dissolved $\mathrm{Cu}$ is present in the form of inorganic or hydrophilic 
336 organic complexes (Sarradin et al. 2009). Redissolution reactions could also occur with

337 other metals, resulting in their higher bioavailability for the mussels. Nevertheless, the

338 highest levels of $\mathrm{Cu}$ and $\mathrm{Fe}$ were found in the digestive gland rather than in the gills. This

339 observation may indicate that suspension-feeding is the main path for both $\mathrm{Cu}$ and $\mathrm{Fe}$

340 uptake. In such a diluted environment, B. azoricus can not rely on the thiotrophic and

341 methanotrophic endosymbionts to fulfill their nutritional needs. Therefore, its ability to

342 feed on suspended organic particles (Le Pennec et al. 1984; Riou et al. 2010), including

343 metal-sulfide organic complexes (Taillefert et al. 2002), gives the vent mussel the

344 opportunity to cope with unpredictable environments but may also increase the input of

345 metals in the digestive gland.

346

347 4.2. Locations $C 1, C 3, C 4$ and $C 5$

348 The distribution of metals between the studied organs was similar for the mussels

349 collected at these four microhabitats. Besides the fact that mussels from location C3

350 showed a higher mean length, than those from the other locations, metal organotropism

351 seems not to be influence by size (Boyden 1974; Mubiana et al. 2006). Iron and Cd

352 accumulated preferentially in the digestive gland and $\mathrm{Cu}$ in the gills. Zinc distribution did

353 not show a particular pattern. In the mixing zone, Sarradin et al., (2009) found a transition

354 area between high sulfide/low oxygen waters and low sulfide/high oxygen waters. The

355 increase of sulfide and dissolved metals enhances the formation of particle metal-sulfide

356 (MS) stable complexes that are less bioavailable for mussels. The formation of such MS

357 complexes was demonstrated earlier for $\mathrm{Cd}, \mathrm{Cu}, \mathrm{Fe}$ and $\mathrm{Zn}$ (Luther et al. 2001; Di Meo-

358 Savoie et al. 2004; Sarradin et al. 2008) and Cu (Sarradin et al. 2009) at EPR and MAR 
359 hydrothermal fields, respectively. The higher concentrations of total dissolved sulfide

360 (TdS) measured at C4 may be responsible for an increased formation of MS that would

361 explain the lower metal levels found in the gills compared to those found in the digestive

362 gland. The gills of the mussels collected at location C5 showed the lowest levels of Fe, in

363 accordance with the lowest $\mathrm{TdFe}$ concentrations measured at $\mathrm{C} 5$. Iron differs from the

364 other metals present at the hydrothermal fields in terms of both its semi-conservative

365 behavior (Luther et al. 2001; Sarradin et al. 2008), partially controlled by dilution

366 processes, and the abundant formation of FeS-metal precipitates (Johnson et al. 1988; Di

367 Meo-Savoie et al. 2004). When sulfide concentrations increase in the mixing zone, the

368 reductive dissolution of soluble organic-Fe is followed by the formation of iron molecular

369 clusters $\left(\mathrm{FeS}_{2}\right)$ (Luther et al. 2001) that react highly with other metals reducing

370 significantly the amounts of bioavailable Fe (Di Meo-Savoie et al. 2004). On the other

371 hand, high levels of Fe were found in the digestive gland of mussels from this location

372 and from $\mathrm{C} 4$. The ability of mussels to ingest suspended particles may be responsible for

373 the high levels of $\mathrm{Fe}$ observed in the digestive gland. Cadmium concentrations in LS

374 hydrothermal fluids are lower than other metal concentrations (Desbruyères et al. 2001;

375 Douville et al. 2002; Kádár et al. 2005a). However, Cd burden in tissues largely depends

376 on its physico-chemical forms in the surrounding water rather than its concentration in

377 the pure fluid. In the reactive mixing zone, $\mathrm{Cd}$ ions may form small particles with $\mathrm{FeS}_{2}$,

378 which may undergo dissolution and/or oxidation reaction (Sarradin et al. 2008).

379 Cadmium has been shown to bind preferentially to ligands such as the inducible

380 metallothioneins (MT) (Bebianno et al. 1991; Cosson 2000; Geret 2000). Metals bound to

381 soluble components are more difficult to excrete. Consequently, prolonged exposure to, 
382 and uptake of, Cd increase the amounts of this metal in tissues (Langston et al. 1998), as

383 observed in the studied organs of C5 mussels. Copper redissolution phenomena may

384 account for its preferential accumulation in the gills rather in the digestive gland of

385 mussels collected from locations $\mathrm{C} 1, \mathrm{C} 3, \mathrm{C} 4$ and $\mathrm{C} 5$. Zinc accumulation patterns were

386 highly variable. They may reflect the variability of $\mathrm{Zn}$ in each of the locations, as well as

387 variable abilities of the vent mussels to reduce $\mathrm{Zn}$ uptake and regulate its storage, as

388 shown previously for coastal mussels (Anandraja et al. 2002; Kondoh et al. 2003; Wang 389 et al. 2005).

390

391 4.3. Location C10

392 The high TdS and TdFe concentrations found at this location, and the resulting 393 formation of $\mathrm{FeS}_{2}$, may be responsible for the observed higher levels of $\mathrm{Fe}$ in the 394 digestive gland compared with those found in the gills. Although $\mathrm{TdCu}$ concentrations 395 were low, $\mathrm{Cu}$ levels were higher in the gills than in the digestive gland. According to 396 Martins et al. (2008), the dominant nutritional strategy of B. azoricus varies with body

397 size and external conditions. Larger individuals rely more on endosymbiosis for their 398 nutritional needs, which explain their spatial distribution closer to $\mathrm{H}_{2} \mathrm{~S}$ and $\mathrm{CH}_{4}$ sources.

399 Since trace metals can be used as electron donors and acceptors by bacteria for generating 400 energy (Di Meo-Savoie et al. 2004), the autotrophic bacterial metabolism may also play a 401 role in metal $(\mathrm{Cu}$ and $\mathrm{Zn})$ bioaccumulation in the gills.

402

403 4.4. MTs 
405 MTs is the homeostasis of essential metals and the prevention of non-essential metal

406 binding to other ligands resulting in a metabolism dysfunction (Roesijadi et al. 1996).

407 However, MT is also involved in an array of protective stress responses, such as food 408 shortage (Cosson 2000; Viarengo et al. 2000; Kondoh et al. 2003), or oxidative damage

409 induced by metal exposure, namely $\mathrm{Cu}$ (Company et al. 2008) or Cd (Geret et al. 2002;

410 Company et al. 2010). MTs levels are almost constant in the mussel tissues collected,

411 suggesting that these organisms may rely on this metalloproteins to cope with their

412 fluctuating immediate environment. However, mussels from location C12 showed higher

413 levels of MT than mussel from C4 and C10, probably due to the high levels of metals in

414 their tissues, namely $\mathrm{Cu}$, and the depleted amounts of reduced compounds essential for

415 their nutrition through the endosymbiont primary production. Moreover, higher MT

416 levels do not always reflect higher bioavailable metals in the environment but also can

417 result from slower MT turnover rates that depend on the associated metals (Cu-MT or 418 Cd-MT e.g.) (Wang et al. 2010).

\section{4.5. TCI and GI}

421 Since the uptake and accumulation of metals in mussels are actively controlled by 422 physiological and biochemical processes (Mubiana et al. 2006), a better nutritional status 423 allows the mussel to cope with metal exposure. Our results corroborate this hypothesis 424 since the mussels with higher physiological conditions (C1 and C4) showed lower metal 425 levels in both tissues. On the contrary, mussels from location C12 showed low TCI and 426 high metal levels. As larger mussels rely preferably on endosymbionts for their nutrition 
427 (Martins et al. 2008), the high TCI found in mussels from C10 may result from an easier

428 access to reduced energy sources in a slightly warmer location. Nevertheless, mussels

429 from locations C3 have similar GI and lower TCI than mussels from C10, which can

430 indicate that mussels from C3 use energetic reserves from other tissues rather than the 431 gills to fulfill their requirements.

\section{Conclusions}

Our study indicates that there is a significant spatial variation of metal

435 accumulation by the vent mussel B. azoricus on the Eiffel Tower edifice. This variation 436 seems to be linked to local environmental conditions that affect the physiological status 437 of the mussels and influence their ability to cope with metal exposure. The high and 438 almost constant levels of metallothioneins in the studied mussels may suggest a 439 background induction for a physiological adaptation to such extreme and fluctuating 440 environments. The vent mussel is an appropriate model for assessing the responses to the 441 metallic load brought by venting fluids. Further studies should address the storage in 442 tissues of metals in insoluble and/or soluble forms in order to understand how B. azoricus 443 manage the metals that it takes up at a subcellular scale.

\section{Acknowledgements}

446 The authors gratefully acknowledge the captain and crew of the $\mathrm{R} / \mathrm{V}$ "Pourquoi 447 Pas?" and Victor 6000 ROV team, during the MoMARETO cruise (IFREMER). Joana 448 Raimundo, Rute Cesário, Carmelina Leal, Luis Pires and Carla Dâmaso for the greatest 449 contribution in the laboratory work. Ricardo Medeiros for Eiffel Tower map edition. The 450 EU research project EXOCET/D, FP6-GOCE-CT-2003-505342, the Portuguese Science 451 Foundation funded program SEAHMA project (FCT/ PDCTM 1999/MAR/15281), the 
452 pluriannual and programmatic funding from FCT and DRCT for research unit \#531 and

453 LA \#9. We also thank Andy Gooday and the anonymous reviewers for their helpful 454 comments on this manuscript. I. Martins works under a FCT PhD grant 455 (SFRH/BD/19736/2004).

\section{6. References}

458 Amiard, J.-C., Amiard-Triquet, C., Barka, S., Pellerin, J., Rainbow, P.S., 2006.

459 Metallothioneins in aquatic invertebrates: their role in metal detoxification and their use 460 as biomarkers. Aquatic Toxicology 76, 160-202.

461 Anandraja, A., Marshall, D.J., Gregory, M.A., McClurg, T.P., 2002. Metal accumulation, 462 filtration and $\mathrm{O} 2$ uptake rates in the mussel Perna perna (Mollusca: Bivalvia) exposed to $463 \mathrm{Hg}^{2+}, \mathrm{Cu}^{2+}$ and $\mathrm{Zn}^{2+}$. Comparative Biochemistry and Physiology 132, 355-363.

464 Bebianno, M.J., Langston, W.J., 1991. Metallothionein induction in Mytilus edulis 465 exposed to cadmium. Marine Biology 108, 91-96.

466 Boyden, C.R., 1974. Trace element content and body size in molluscs. Nature 251, 311467314.

468 Charlou, J.L., Donval, J.P., Douville, E., Jean-Baptiste, P., Radford-Knoery, J., Fouquet, 469 Y., Dapoigny, A., Stievenard, M., 2000. Compared geochemical signatures and the 470 evolution of Menez Gwen $\left(37^{\circ} 50^{\prime} \mathrm{N}\right)$ and Lucky Strike $\left(37^{\circ} 17^{\prime} \mathrm{N}\right)$ hydrothermal fluids, 471 south of the Azores Triple Junction on the Mid-Atlantic Ridge. Chemical Geology 171, $472 \quad 49-75$

473 Childress, J.J., Fisher, C.R., 1992. The biology of hydrothermal vent animals: 474 Physiology, biochemistry and autotrophic symbioses. Oceanography and Marine 475 Biology: An Annual Review 30, 337-441. 
476 Colaço, A., Bustamante, P., Fouquet, Y., Sarradin, P.-M., Santos, R.S., 2006.

477 Bioaccumulation of $\mathrm{Hg}, \mathrm{Cu}$, and $\mathrm{Zn}$ in the Azores triple junction hydrothermal vent fields

478 food web. Chemosphere 65, 2260-2267.

479 Colaço, A., Prieto, C., Martins, A., Figueiredo, M., Lafon, V., Monteiro, M., Bandarra,

480 N.M., 2009. Seasonal variations in lipid composition of the hydrothermal vent mussel

481 Bathymodiolus azoricus from the Menez Gwen vent field. Marine Environmental 482 Research 67, 146-152.

483 Company, R., Serafim, A., Bebianno, M.J., Cosson, R., Shillito, B., Fiala-Médioni, A., 484 2004. Effect of cadmium, copper and mercury on antioxidant enzyme activities and lipid 485 peroxidation in the gills of the hydrothermal vent mussel Bathymodiolus azoricus. Marine 486 Environmental Research 58, 377-381.

487 Company, R., Serafim, A., Cosson, R.P., Fiala-Médioni, A., Camus, L., Colaço, A., 488 Santos, R.S., Bebianno, M.J., 2008. Antioxidant biochemical responses to long-term 489 copper exposure in Bathymodiolus azoricus from Menez-Gwen hydrothermal vent. 490 Science of the Total Environment 407-417.

491 Company, R., Serafim, A., Cosson, R.P., Fiala-Médioni, A., Camus, L., Santos, R.S., 492 Bebianno, M.J., 2010. Sub-lethal effects of cadmium on the antioxidant defense system 493 of the hydrothermal vent mussel Bathymodiolus azoricus. Ecotoxicology and 494 Environmental Safety 73, 788-795.

495 Cosson, R.P., Vivier, J.P., 1995. Impact of metals on hydrothermal vent communities: 496 bioaccumulation and detoxication processes. Marine Environmental Research 39, 349. 
497 Cosson, R.P., 2000. Bivalve metallothionein as a biomarker of aquatic ecosystem 498 pollution by trace metals: Limits and perspectives. Cellular and Molecular Biology 46, $499 \quad 295-309$.

500 Cosson, R.P., Thiebaut, E., Company, R., Castrec-Rouelle, M., Colaço, A., Martins, I., 501 Sarradin, P.M., Bebianno, M.J., 2008. Spatial variation of metal bioaccumulation in the 502 hydrothermal vent mussel Bathymodiolus azoricus. Marine Environmental Research 65, $503 \quad 405-415$.

504 Cuvelier, D., Sarrazin, J., Colaço, A., Copley, J., Desbruyères, D., Glover, A.G., Tyler, 505 P., Santos, R.S., 2009. Distribution and spatial variation of hydrothermal faunal 506 assemblages at Lucky Strike (Mid-Atlantic Ridge) revealed by high-resolution video 507 image analysis. Deep-Sea Research Part I 56, 2026-2040.

508 De Busserolles, F., Sarrazin, J., Gauthier, O., Gelinas, Y., Fabri, M.C., Sarradin, P.M., 509 Desbruyères, D., Biscoito, M., Caprais, J.C., Colaço, A., Comtet, T., Crassous, P., 510 Fouquet, Y., Khripounoff, A., Le Bris, N., Olu, K., Riso, R., Sarradin, P.-M., Segonzac, 511 M., Vangriesheim, A., 2001. Variations in deep-sea hydrothermal vent communities on 512 the Mid-Atlantic Ridge near the Azores plateau. Deep-Sea Research Part I 48, 13255131346.

514 Desbruyères, D., 2009. Are spatial variations in the diets of hydrothermal fauna linked to 515 local environmental conditions? Deep-Sea Research Part II 56, 1649-1664.

516 Di Meo-Savoie, C.A., Luther, G.W., Cary, S.C., 2004. Physicochemical characterization 517 of the microhabitat of the epibionts associated with Alvinella pompejana, a hydrothermal 518 vent annelid. Geochimica et Cosmochimica Acta 68, 2055-2066. 
519 Douville, E., Charlou, J.L., Oelkers, E.H., Bienvenu, P., Colon, C.F.J., Donval, J.P.,

520 Fouquet, Y., Prieur, D., Appriou, P., 2002. The Rainbow vent fluids (36 degrees 14 ' N,

521 MAR): the influence of ultramafic rocks and phase separation on trace metal content in

522 Mid-Atlantic Ridge hydrothermal fluids. Chemical Geology 184, 37-48.

523 Duperron, S., Bergin, C., Zielinski, F., Blazejak, A., Pernthaler, A., McKiness, Z.P.,

524 DeChaine, E., Cavanaugh, C.M., Dubilier, N., 2006. A dual symbiosis shared by two

525 mussel species, Bathymodiolus azoricus and Bathymodiolus puteoserpentis (Bivalvia:

526 Mytilidae), from hydrothermal vents along the northern Mid-Atlantic Ridge.

527 Environmental Microbiology 8, 1441-1447.

528 Feely, R.A., Gendron, J.F., Baker, E.T., Lebon, G.T., 1994. Hydrothermal plumes along

529 the East Pacific Rise, $8^{\circ} 40^{\prime}$ to $11^{\circ} 50^{\prime} \mathrm{N}$ : Particle distribution and composition. Earth and 530 Planetary Science Letters 128, 19-36.

531 Fiala-Médioni, A., McKiness, Z.P., Dando, P., Boulegue, J., Mariotti, A., Alayse-Danet,

532 A.M., Robinson, J.J., Cavanaugh, C.M., 2002. Ultrastructural, biochemical, and

533 immunological characterization of two populations of the mytilid mussel Bathymodiolus

534 azoricus from the Mid-Atlantic Ridge: evidence for a dual symbiosis. Marine Biology

$535 \quad 141,1035-1043$.

536 Fouquet, Y., Ondreas, H., Charlou, J.L., Donval, J.P., Radford-Knoery, J., Costa, I., 537 Lourenco, N., Tivey, M.K., 1995. Atlantic lava lakes and hot vents. Nature 377, 201-201.

538 Geret, F., Rousse, N., Riso, R., Sarradin, P.-M., Cosson, R.P., 1998. Metal

539 compartmentalization and metallothionein isoforms in mussels from the Mid-Atlantic

540 Ridge; preliminary approach to the fluid-organism relationship. Cahiers de Biologie

541 Marine 39, 291-293. 
542 Geret, F., 2000. Synthèse de métallothionéines chez deux bivalves (l'huître et la moule)

543 en réponse à une contamination métallique par la voie directe et par la voie trophique. In:

544 Thesis, Université de Nantes, Nantes,

545 Geret, F., Riso, R., Sarradin, P.-M., Caprais, J.-C., Cosson, R., 2002. Metal

546 bioaccumulation and storage forms in the shrimp, Rimicaris exoculata, from the Rainbow

547 hydrothermal field (Mid-Atlantic Ridge); preliminary approach to the fluid-organism

548 relationship. Cahiers de Biologie Marine 43, 43-52.

549 Hamza-Chaffai, A., Amiard, J.C., Pellerin, J., Joux, L., Berthet, B., 2000. The potential

550 use of metallothionein in the clam Ruditapes decussatus as a biomarker of in situ metal

551 exposure. Comparative Biochemistry and Physiology 127, 185-197.

552 Hardivillier, Y., Denis, F., Demattei, M.V., Bustamante, P., Laulier, M., Cosson, R., 553 2006. Metal influence on metallothionein synthesis in the hydrothermal vent mussel

554 Bathymodiolus thermophilus. Comparative Biochemistry and Physiology 143, 321-332.

555 Johnson, K.S., Childress, J.J., Beehler, C.L., 1988. Short-term temperature variability in

556 the Rose Garden hydrothermal vent field- an unstable deep-sea environment. Deep-Sea

557 Research Part I 35, 1711-1721.

558 Kádár, E., Bettencourt, R., Costa, V., Santos, R.S., Lobo-da-Cunha, A., Dando, P., 2005a.

559 Experimentally induced endosymbiont loss and re-acquirement in the hydrothermal vent

560 bivalve Bathymodiolus azoricus. The Journal of Experimental Biology 318, 99-110.

561 Kádár, E., Costa, V., Martins, I., Santos, R., Powell, J., 2005b. Enrichment in trace metals

562 (Al, Mn, $\mathrm{Co}, \mathrm{Mo}, \mathrm{Cd}, \mathrm{Fe}, \mathrm{Zn}, \mathrm{Pb}$ and $\mathrm{Hg}$ ) of macro-invertebrate habitats at hydrothermal

563 vents along the Mid-Atlantic Ridge. Hydrobiologia 548, 191-205. 
564 Kondoh, M., Imada, N., Kamada, K., Tsukahara, R., Higashimoto, M., Takiguchi, M.,

565 Watanabe, Y., Sato, M., 2003. Property of metallothionein as a Zn pool differs depending

566 on the induced condition of metallothionein. Toxicology Letters 142, 11-18.

567 Langston, W.J., Bebianno, M.J., Mingjiang, Z., 1989. A comparison of metal-binding 568 proteins and cadmium metabolism in the marine mollusks Littorina littorea (Gastropoda), 569 Mytilus edulis and Macoma balthica (Bivalvia) Marine Environmental Research 28, 195 570200.

571 Langston, W.J., Bebianno, M.J., Burt, G., 1998. Metal handling strategies in molluscs. In:

572 Langston, W.J., Bebianno, M.J. (Ed.) Metal Metabolism in Aquatic Environments, 573 Chapmann \& Hall, London, pp. 219-284

574 Le Bris, N., Sarradin, P.-M., Pennec, S., 2001. A new deep-sea probe for in situ pH 575 measurement in the environment of hydrothermal vent biological communities. Deep-Sea 576 Research Part I 48, 1941-1951.

577 Le Bris, N., Sarradin, P.-M., Caprais, J., 2003. Contrasted sulphide chemistries in the 578 environment of 13 degrees N EPR vent fauna. Deep-Sea Research Part I 50, 737-747.

579 Le Pennec, M., Prieur, D., Lucas, A., 1984. Studies on the feeding of a hydrothermal-vent 580 mytilid from the East Pacific Rise. Proc. 19th European Marine Biology Symposium 159581166.

582 Le Pennec, M., Donval, A., Herry, A., 1990. Nutritional strategies of the hydrothermal 583 ecosystem bivalves. Progress in Oceanography 24, 71-80.

584 Luther, G.W., Rozan, T.F., Taillefert, M., Nuzzio, D.B., Di Meo, C., Shank, T.M., Lutz, 585 R.A., Cary, S.C., 2001. Chemical speciation drives hydrothermal vent ecology. Nature $586410,813-816$. 
Martins, I., Costa, V., Porteiro, F., Cravo, A., Santos, R., 2001. Mercury concentrations in

588 invertebrates from Mid-Atlantic Ridge hydrothermal vent fields. Journal of the Marine

589 Biological Association of the United Kingdom 81, 913-915.

590 Martins, I., Colaço, A., Dando, P.R., Martins, I., Desbruyères, D., Sarradin, P.M.,

591 Marques, J.C., Santos, R., 2008. Size-dependent variations on the nutritional pathway of

592 Bathymodiolus azoricus demonstrated by a C-flux model. Ecological Modelling 217, 59-

59371.

594 Martins, I., Colaço, A., Santos, R.S., Lesongeur, F., Godfroy, A., Sarradin, P.M., Cosson,

595 R.P., 2009. Relationship between the occurrence of filamentous bacteria on

596 Bathymodiolus azoricus shell and the physiological and toxicological status of the vent

597 mussel. Journal of Experimental Marine Biology and Ecology 376, 1-6.

598 Mubiana, V., Vercauteren, K., Blust, R., 2006. The influence of body size, condition

599 index and tidal exposure on the variability in metal bioaccumulation in Mytilus edulis.

600 Environmental Pollution 144, 272-279.

601 Olafson, R.W., Sim, R.G., 1979. Electrochemical approach to quantification and 602 characterization of metallothioneins. Analytical Biochemistry 100, 343-351.

603 Ondréas, H., Cannat, M., Fouquet, Y., Normand, A., Sarradin, P.-M., Sarrazin, J., 2009.

604 Recent volcanic events and the distribution of hydrothermal venting at the Lucky Strike 605 hydrothermal field, Mid-Atlantic Ridge. Geochemistry Geophysics Geosystems 10.

606 Riou, V., Halary, S., Duperron, S., Bouillon, S., Elskens, M., Bettencourt, R., Santos, 607 R.S., Dehairs, F., Colaço, A., 2008. Influence of $\mathrm{CH}_{4}$ and $\mathrm{H}_{2} \mathrm{~S}$ availability on symbiont 608 distribution, carbon assimilation and transfer in the dual symbiotic vent mussel 609 Bathymodiolus azoricus. Biogeosciences 5, 1681-1691. 
610 Riou, V., Colaço, A., Bouillon, S., Khripounoff, A., Dando, P., Mangion, P., Chevalier,

611 E., Korntheuer, M., Santos, R.S., Dehairs, F., 2010. Mixotrophy in the deep sea: a dual

612 endosymbiotic hydrothermal mytilid assimilates dissolved and particulate organic matter.

613 Marine Ecology Progress Series 405, 187-201.

614 Riso, R.D., LeCorre, P., Chaumery, C.J., 1997. Rapid and simultaneous analysis of trace

615 metals $(\mathrm{Cu}, \mathrm{Pb}$ and $\mathrm{Cd})$ in seawater by potentiometric stripping analysis. Analytica

616 Chimica Acta 351, 83-89.

617 Roesijadi, G., Hansen, K.M., Unger, M.E., 1996. Cadmium-induced metallothionein 618 expression during embryonic and early larval development of the mollusc Crassostrea 619 virginica. Toxicology and Applied Pharmacology 140, 356-363.

620 Sarradin, P.-M., Caprais, J.-C., Riso, R., Kerouel, R., Aminot, A., 1999. Chemical 621 environment of the hydrothermal mussel communities in the Lucky Strike and Menez 622 Gwen vent fields, Mid Atlantic Ridge. Cahiers de Biologie Marine 40, 93-104.

623 Sarradin, P.-M., Lannuzel, D., Waeles, M., Crassous, P., Le Bris, N., Caprais, J.C.,

624 Fouquet, Y., Fabri, M.C., Riso, R., 2008. Dissolved and particulate metals (Fe, Zn, Cu, $625 \mathrm{Cd}, \mathrm{Pb})$ in two habitats from an active hydrothermal field on the EPR at 13 degrees $\mathrm{N}$. 626 Science of the Total Environment 392, 119-129.

627 Sarradin, P.-M., Waeles, M., Bernagout, S., Le Gall, C., Sarrazin, J., Riso, R., 2009. 628 Speciation of dissolved copper within an active hydrothermal edifice on the Lucky Strike 629 vent field (MAR, 37 degrees N). Science of the Total Environment 407, 869-878.

630 Sarrazin, J., Juniper, S.K., Massoth, G., Legendre, P., 1999. Physical and chemical 631 factors influencing species distributions on hydrothermal sulfide edifices of the Juan de 632 Fuca Ridge, Northeast Pacific. Marine Ecology Progress Series 190, 89-112. 
633 Sarrazin, J., Sarradin, P.-M., participants, M.c., 2006. Momareto : a cruise dedicated to

634 the spatial-temporal dynamics and the adaptations of hydrothermal vent fauna on the

635 Mid-Atlantic Ridge. InterRidge News 15, 24-33.

636 Sato, M., Bremner, I., 1993. Oxygen free-radicals and metallothionein. Free Radical

637 Biology and Medicine 14, 325-337.

638 Simkiss, K., 1998. Mechanisms of metal uptake. In: Langston, W.J., Bebianno, M.J.

639 (Eds.), Metal metabolism in aquatic environments, Chapman \& Hall, London, p. 448

640 Stewart, F., Newton, I., Cavanaugh, C., 2005. Chemosynthetic endosymbioses:

641 adaptations to oxic-anoxic interfaces. TRENDS in Microbiology 13, 439-448.

642 Taillefert, M., Hover, V.C., Rozan, T.F., Theberge, S.M., Luther, G.W., 2002. The

643 influence of sulfides on soluble organic-Fe (III) in anoxic sediment pore waters. Estuaries $644 \quad 25,1088-1096$.

645 Thompson, J.A.J., Cosson, R.P., 1984. An improved electrochemical method for the 646 quantification of metallothioneins in marine organisms. Marine Environmental Research $647 \quad 11,137-152$.

648 Trefry, J., Trocine, R., Klinkhammer, G., Rona, P., 1985. Iron and copper enrichment of 649 suspended particles in dispersed hydrothermal plumes along the Mid-Atlantic Ridge.

650 Geophysical Research Letters 12, 506-509.

651 Trocine, R., Trefry, J., 1988. Distribution and chemistry of suspended particles from an 652 active hydrothermal vent site on the Mid-Atlantic Ridge at $26^{\circ} \mathrm{N}$ Earth and Planetary 653 Science Letters 88, 1-15.

654 Tunnicliffe, V., 1991. The Biology of Hydrothermal Vents - Ecology and Evolution. 655 Oceanography and Marine Biology 29, 319-407. 
656 Viarengo, A., Nott, J.A., 1993. Mechanisms of heavy metal cation homeostasis in marine

657 invertebrates. Comparative Biochemistry and Physiology 104, 355-372.

658 Viarengo, A., Burlando, B., Ceratto, N., Panfoli, I., 2000. Antioxidant role of 659 metallothioneins: A comparative overview. Cellular and Molecular Biology 46, 407-417.

660 Voets, J., Talloen, W., De Tender, T., van Dongen, S., Covaci, A., Blust, R., Bervoets, L.,

661 2006. Microcontaminant accumulation, physiological condition and bilateral asymmetry

662 in zebra mussels (Dreissena polymorpha) from clean and contaminated surface waters.

663 Aquatic Toxicology 79, 213-225.

664 Vuillemin, R., Le Roux, D., Dorval, P., Bucas, K., Sudreau, J.P., Hamon, M., Le Gall, C.,

665 Sarradin, P.-M., 2009. CHEMINI: A new in situ chemical miniaturized analyzer. Deep-

666 Sea Research Part I 56, 1391-1399.

667 Wang, W.X., Rainbow, P.S., 2005. Influence of metal exposure history on trace metal

668 uptake and accumulation by marine invertebrates. Ecotoxicology and Environmental

669 Safety $61,145-159$.

670 Wang, W.X., Rainbow, P.S., 2010. Significance of metallothioneins in metal 671 accumulation kinetics in marine animals. Comparative Biochemistry and Physiology 152, $6721-8$.

673 Zar, J.H., 1999. Biostatistical Analysis. Prentice-Hall New Jersey. 
Table 1

Mean values $\left( \pm \mathrm{SD}\right.$ ) of $\mathrm{Cd}, \mathrm{Cu}, \mathrm{Fe}$ and $\mathrm{Zn}$ levels, in $\mu \mathrm{g} \mathrm{g}^{-1}$ dry weight (d.w), found in certified reference material, lobster hepatopancreas TORT-2 (NRCC-Canada) and mussel tissue CE278 (ERM-Belgium). $\mathrm{n}$ represents the number of samples analyzed.

\begin{tabular}{ccccc}
\hline Certified reference material & & $\mathrm{n}$ & $\begin{array}{c}\text { Certified } \\
\mu g^{-1}(\mathrm{~d} . w)\end{array}$ & $\begin{array}{c}\text { Observed } \\
\mu \mathrm{gg}^{-1}(\mathrm{~d} . \mathrm{w})\end{array}$ \\
\hline TORT-2 & $\mathrm{Cd}$ & 21 & $26.7 \pm 0.6$ & $25.6 \pm 1.2$ \\
& $\mathrm{Cu}$ & 9 & $106 \pm 10$ & $105 \pm 3$ \\
& $\mathrm{Fe}$ & 12 & $105 \pm 13$ & $106 \pm 6$ \\
$\mathrm{CE} 278$ & $\mathrm{Zn}$ & 11 & $83.1 \pm 1.7$ & $110 \pm 8$ \\
\hline
\end{tabular}

Table 2

Mean values $( \pm \mathrm{SD})$ of environmental conditions (temperature $(\mathrm{T}), \mathrm{pH}$, total dissolved sulfide $(\mathrm{TdS})$, total dissolved iron ( $\mathrm{TdFe})$ and total dissolved copper $(\mathrm{TdCu}))$ in each of the 6 sampled locations. Results extracted from the article of De Busserolles et al. (2009). $n=2$ to 5 water samples per location.

\begin{tabular}{cccccc}
\hline Location & $\mathrm{T}\left({ }^{\circ} \mathrm{C}\right)$ & $\mathrm{pH}$ & $\mathrm{TdS}\left(\mu \mathrm{mol}^{-1}\right)$ & $\mathrm{TdFe}\left(\mu \mathrm{mol} \mathrm{1^{-1 } )}\right.$ & $\mathrm{TdCu}\left(\mu \mathrm{mol} 1^{-1}\right)$ \\
\hline $\mathrm{C} 1$ & $4.9 \pm 0.5$ & $6.9 \pm 0.2$ & $1.3 \pm 0.8$ & $0.4 \pm 0.4$ & $1.6 \pm 0.9$ \\
$\mathrm{C} 3$ & $5.4 \pm 0.5$ & $6.7 \pm 0.2$ & $3.4 \pm 1.8$ & $0.4 \pm 0.2$ & $1.4 \pm 0.2$ \\
$\mathrm{C} 4$ & $5.7 \pm 0.5$ & $6.6 \pm 0.1$ & $6.1 \pm 4.4$ & $1.7 \pm 0.8$ & $2.1 \pm 1.3$ \\
$\mathrm{C} 5$ & $5.1 \pm 0.5$ & $6.9 \pm 0.1$ & $1.9 \pm 0.9$ & $0.1 \pm 0.2$ & $0.8 \pm 0.4$ \\
$\mathrm{C} 10$ & $8.8 \pm 2.7$ & $6.0 \pm 0.4$ & $34.9 \pm 22.0$ & $5.3 \pm 3.6$ & $0.5 \pm 0.7$ \\
$\mathrm{C} 12$ & $4.8 \pm 0.3$ & $7.1 \pm 0.6$ & $2.3 \pm 1.1$ & $0.4 \pm 0.4$ & $2.6 \pm 2.2$ \\
\hline
\end{tabular}

Table 3

Number (n) and shell size ( \pm SD) of the mussels collected in each of the 6 sampled locations.

\begin{tabular}{ccccc}
\hline Location & $\mathrm{n}$ & Length $(\mathrm{cm})$ & Width $(\mathrm{cm})$ & Height $(\mathrm{cm})$ \\
\hline C1 & 20 & $5.1 \pm 0.8$ & $2.4 \pm 0.3$ & $1.9 \pm 0.3$ \\
C3 & 20 & $6.1 \pm 0.7$ & $3.0 \pm 0.3$ & $2.2 \pm 0.3$ \\
C4 & 15 & $5.2 \pm 1.0$ & $2.7 \pm 0.3$ & $2.0 \pm 0.3$ \\
C5 & 20 & $5.2 \pm 0.8$ & $2.6 \pm 0.3$ & $1.9 \pm 0.3$ \\
C10 & 10 & $7.0 \pm 0.7$ & $3.4 \pm 0.3$ & $2.7 \pm 0.3$
\end{tabular}


C12

$20 \quad 5.4 \pm 0.9$

$2.7 \pm 0.5$

$2.0 \pm 0.4$ 


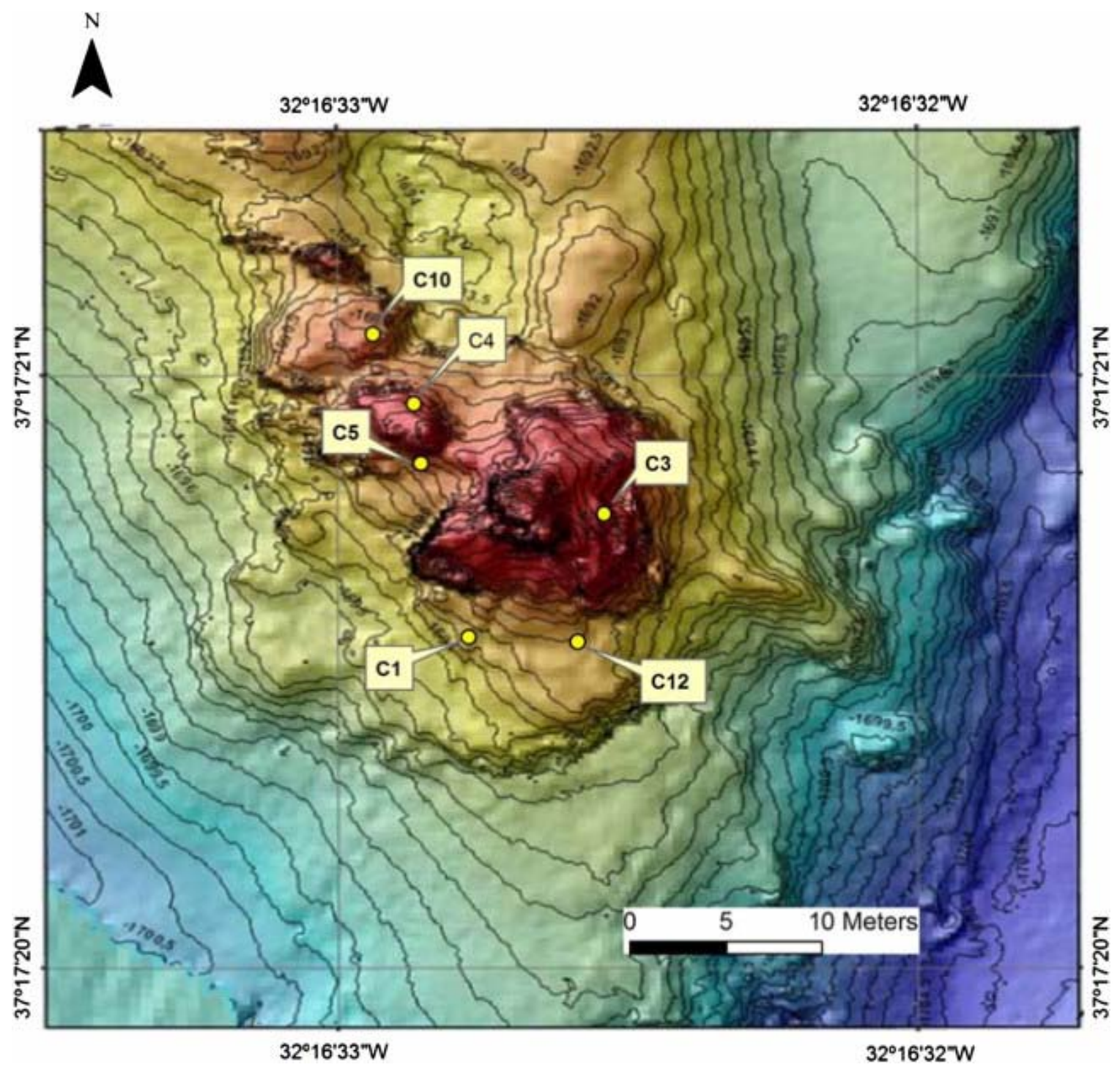

Fig. 1. Bathymetric map of Eiffel Tower active edifice, located in Lucky Strike vent field, and position of the 6 sampled locations: C1, C3, C4, C5, C10 and C12. Adapted from Sarrazin et al. (2006). 

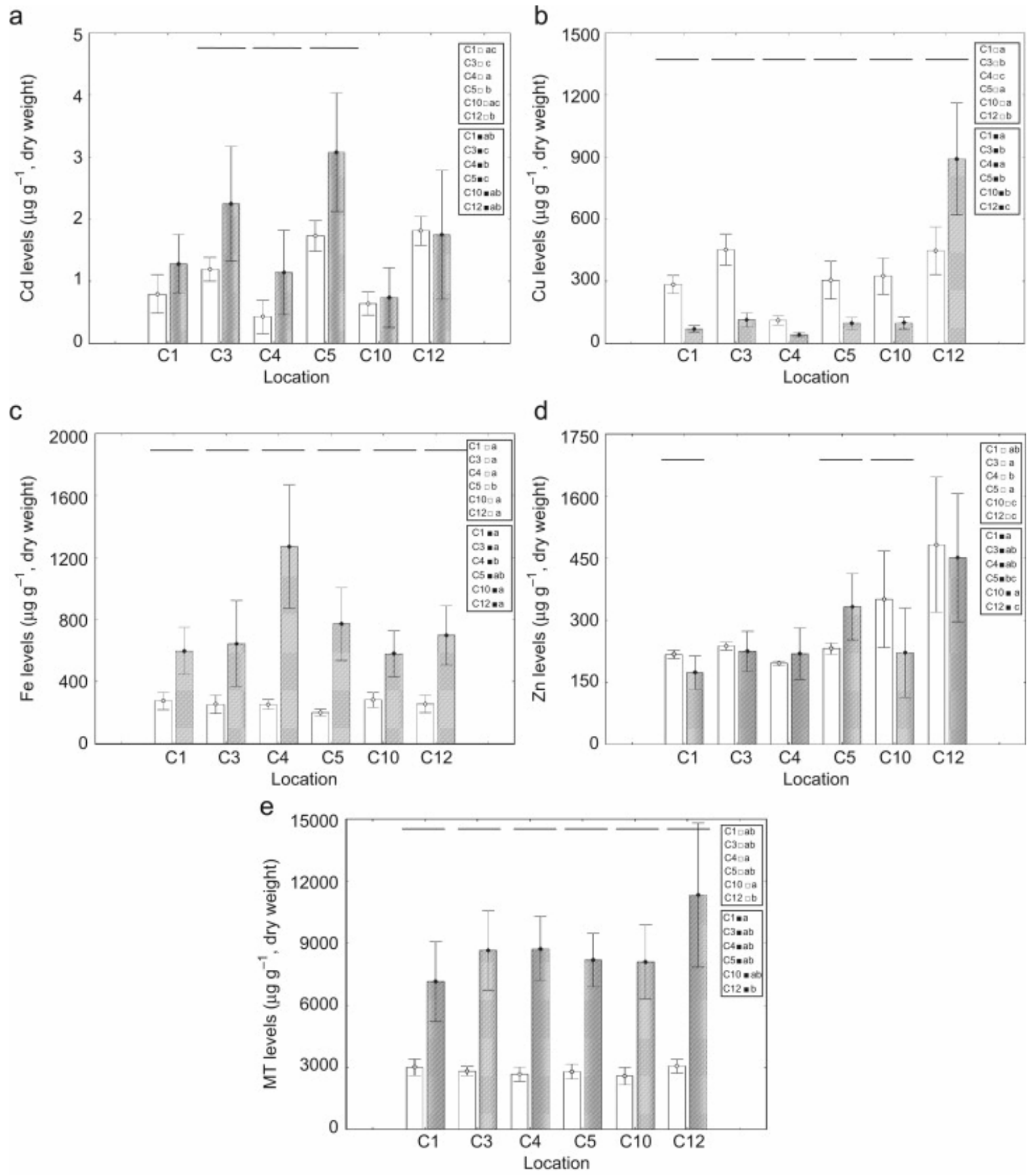

Fig. 2. Mean levels ( $\mu \mathrm{g} g-1$, dry weight) of $\mathrm{Cd}(\mathrm{a}), \mathrm{Cu}(\mathrm{b}), \mathrm{Fe}(\mathrm{c}), \mathrm{Zn}(\mathrm{d})$ and MT (e) in gills (open columns) and digestive gland (shade columns) of mussels collected at each location (C1, C3, C4, $\mathrm{C} 5, \mathrm{C} 10$ and C12). Vertical bars represent the standard deviation of the mean. Symbol (-) represents significant differences between tissues for each location. Similar letters indicate no statistical difference among locations for gills $(\square)$ and for digestive gland ( $\mathbf{\square})$. 
a

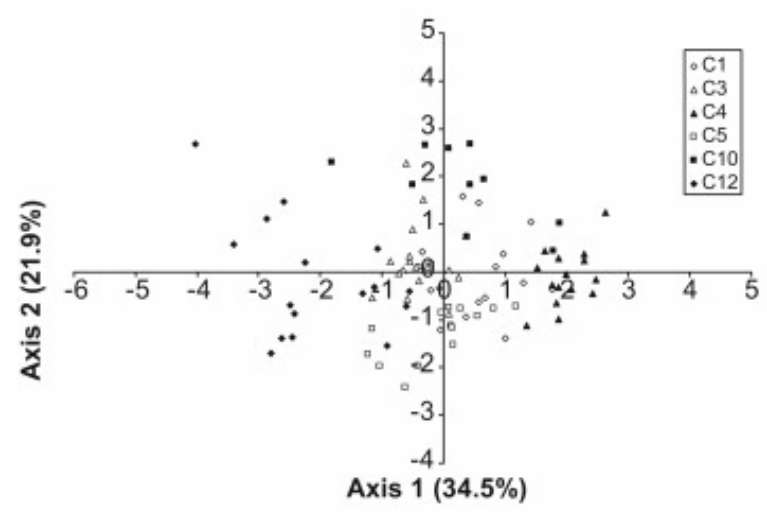

b

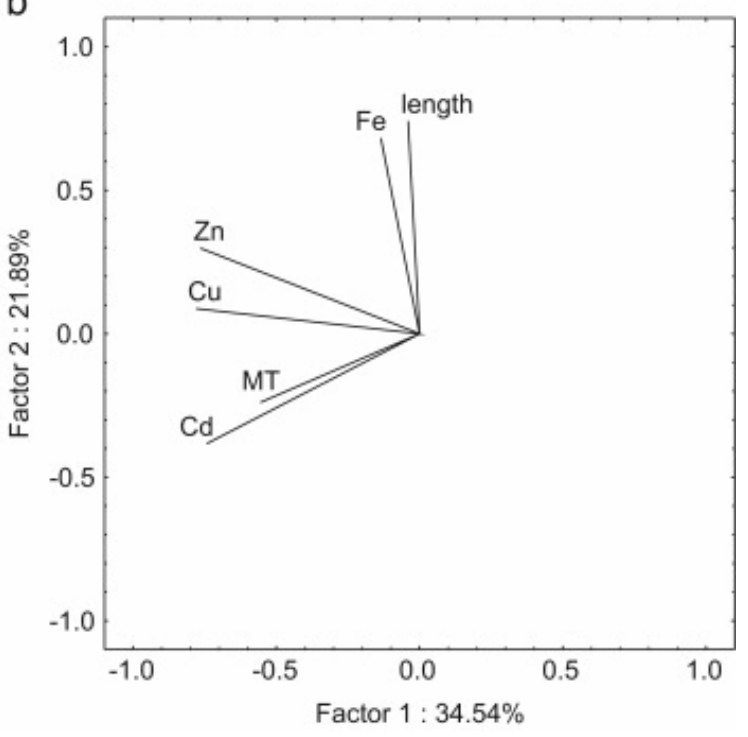

Fig. 3. First plane principal component analysis (PCA) of mussel gill metal levels at each location (C1, C3, C4, C5, C10 and C12). (a) Individual scores. (b) Descriptor scores. All variables were standardized before analysis.

a

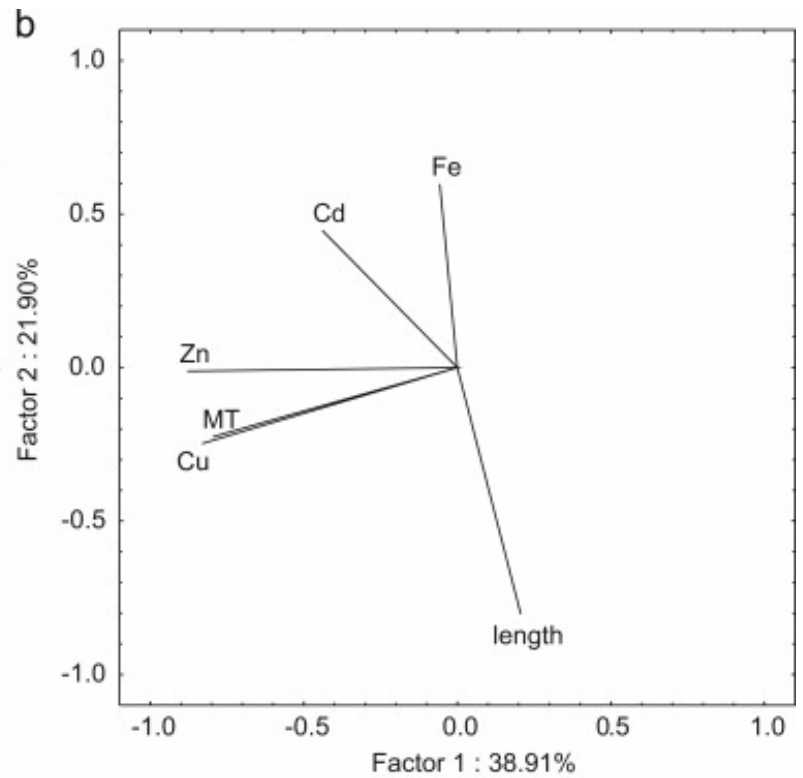

Fig. 4. First plane principal component analysis (PCA) of mussel digestive gland metal levels at each microhabitat (C1, C3, C4, C5, C10 and C12). (a) Individual scores. (b) Descriptor scores. All variables were standardized before analysis. 


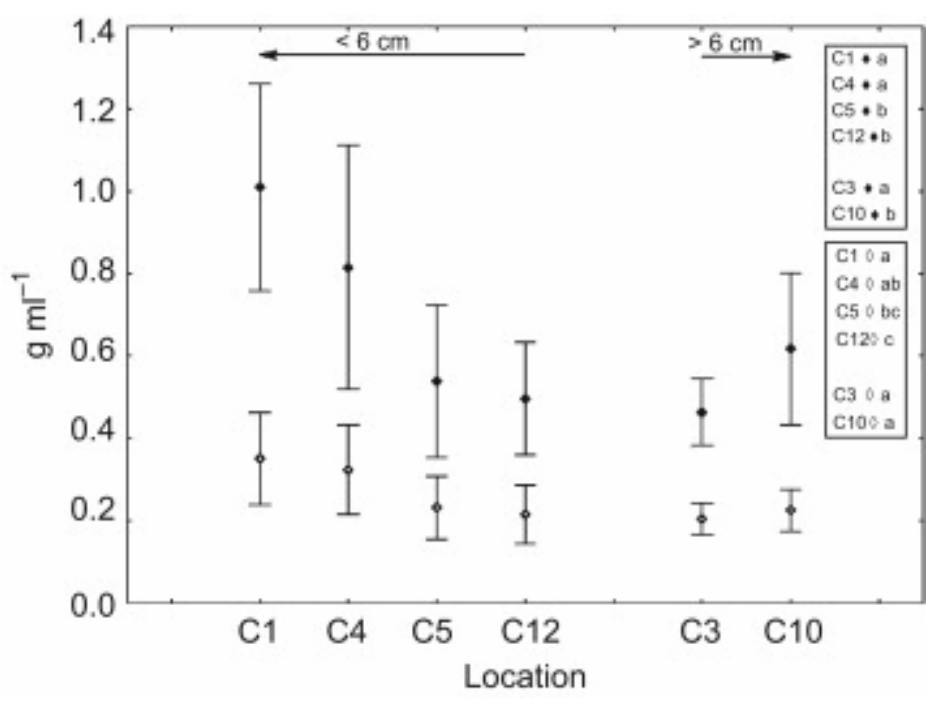

Fig. 5.

Mean $\left(\mathrm{g} \mathrm{ml}^{-1}\right) \mathrm{TCl}$ (closed diamonds) and $\mathrm{Gl}$ (open diamonds) in mussels collected at each location (C1, C4, C5, C12 and C3, C10). Locations are separated by mussels shell length $(<6 \mathrm{~cm}>)$. Vertical bars represent the standard deviation of the mean. Similar regular letters indicate no statistical difference among locations with mussels length $<6 \mathrm{~cm}($ ) and similar italic letters indicate no statistical difference among locations with mussels length $>6 \mathrm{~cm}($ ). 